Dr RATOMIR MILIKIĆ, naučni saradnik

Institut za savremenu istoriju

UDK 341.176(497.1:4-672EU)"1980/2003"

Beograd, Trg Nikole Pašića 11

341.176(497.11:4-672EU)"2003/2013"

$327(497.1) " 1980 / 2003 "$

\title{
O DESETOGODIŠNJICI ČLANSTVA SRBIJE U SAVETU EVROPE 2003-2013*
}

\begin{abstract}
APSTRAKT: $U$ članku se razmatraju problemi na koje je Republika Srbija (SRJ i SCG) nailazila na putu ka punopravnom članstvu u Savetu Evrope. Bilo je tu brojnih prepreka, koje su u mnogo čemu bile jedinstvene i za SRJ. Savezna skupština je 4. februara 2003. proglasila Ustavnu povelju Državne zajednice Srbija i Crna Gora. Time je prestala da postoji SRJ, a 26. marta Komitet ministara pozvao je SCG u punopravno članstvo; prijem je konačno realizovan 3. aprila 2003, ali uz poseban, dotad ni u jednoj zemlji primenjen mehanizam dvostrukog monitoringa. U narednih deset godina, SCG, a od 2006, njen pravni naslednik Republika Srbija neretko je bivala u prilici da, učestvujući u radu Saveta Evrope i njegovih radnih tela $i$ organizacija,brani svoje interese vezane za teritorijalni integritet $i$ suverenitet. Najčešća pitanja koja su se postavljala odnosila su se na Kosovo i Metohiju, prava nacionalnih manjina, prava verskih zajednica i saradnju sa Haškim tribunalom. Najznačajniji dokument PSSE u ovom periodu koji se ticao Srbije bio je izveštaj Dika Martija o trgovini organima na KiM. Svojevrsnu satisfakciju za sve peripetije u prvoj deceniji članstva Republike Srbije i deceniju izolovanosti i jednostranih osuda, koja joj je je prethodila, predstavljalo je predsedavanje Srbije Komitetom ministara Saveta Evrope u periodu maj-novembar 2007. koje je ocenjeno kao konačna potvrda posvećenosti Republike Srbije evropskim vrednostima, poštovanju ljudskih prava i vladavini prava.
\end{abstract}

Ključne reči: Narodna skupština Republike Srbije, Savet Evrope, parlamentarna diplomatija, Dik Marti, uslovi za članstvo, evropska politika

Srbija je 2003. godine, posle napornog višegodišnjeg puta, konačno postala član Saveta Evrope. Učinila je to u sklopu Državne zajednice Srbije i Crne Gore, koja je primljena u punopravno članstvo 3. aprila 2003, na

* Rad je deo projekta Konflikti i krize: saradnja i razvoj u Srbiji i regionu u 19. i 20. veku (47030), koji finansira Ministarstvo prosvete, nauke i tehnološkog razvoja Republike Srbije. 
osnovu Rezolucije Komiteta ministara od 26. marta te godine. ${ }^{1}$ Kako je, međutim, Ustavnom poveljom utvrđeno da Srbija nasleđuje pravo na međunarodno-pravni subjektivitet $u$ slučaju istupanja Crne Gore iz državne zajednice, ${ }^{2}$ to se proglašenjem nezavisnosti Crne Gore promenilo samo ime pod kojim je Srbija članica Saveta Evrope, njeno članstvo u SE faktički teče neprekidno od 3. aprila 2003. To je zvanično potvrđeno odlukom Komiteta ministara SE od 14. juna 2006, u kojoj se navodi da je Srbija ostvarila kontinuitet članstva u Organizaciji i pri konvencijama SE, ${ }^{3}$ pošto je Crna Gora 3. juna iste godine proglasila nezavisnost.

Beograd je punopravno članstvo u Savetu Evrope prvi put zvanično zatražio 7. februara 1990. Zahtevu je prethodila poseta predsednika Parlamentarne skupštine Saveta Evrope Andersa Bjorka Beogradu od 16. do 18. januara 1990. Formalni domaćin bio mu je Slobodan Gligorijević, predsednik Skupštine SFR Jugoslavije, a tom prilikom sreo se i sa predsednikom Predsedništva SFRJ Janezom Drnovšekom, predsednikom SIV-a Antom Markovićem, šefom jugoslovenske diplomatije Budimirom Lončarom, saveznim sekretarom za pravdu dr Vladimirom Kambovskim, predsednikom Saveznog ustavnog suda Dušanom Štrpcem, te zvaničnicima Skupštine SFRJ Bogdanom Glumac Levakov, Miranom Mejakom, Aleksandrom Simovićem, Milomirom Đurovićem i Dušanom Popovskim (kao šefom posmatračke delegacije SFRJ u PSSE).

Glavni motiv posete bila je činjenica da su stizale najave iz zvaničnog Beograda da je Jugoslavija spremna da uđe u proceduru zvaničnog prijema $u$ članstvo te evropske organizacije. Prilikom posete usvojena je i zajednička deklaracija o budućoj saradnji između SE i SFRJ. Skupština SFRJ je usvojila preporuku jugoslovenskoj vladi da otpočne proceduru za članstvo u SE, a tom prilikom se poslanicima jugoslovenskog parlamenta obratio i predsednik PSSE kao pozvani govornik. U razgovorima na svim nivoima predsednik PSSE se uverio da jugoslovenske vlasti žele da u najskorijem roku otpočnu proceduru prijema u SE, pa je prilikom posete bila je ugovorena mapa puta za članstvo $u$ organizaciji, te

\footnotetext{
https://wcd. coe. int

${ }^{2}$ Ustavna povelja, član 60: ,...U slučaju istupanja države Crne Gore iz državne zajednice Srbija i Crna Gora, međunarodni dokumenti koji se odnose na Saveznu Republiku Jugoslaviju, posebno Rezolucija 1244 SB UN, odnosili bi se i u celosti bi važili za državu Srbiju, kao sledbenika. Država članica koja iskoristi pravo istupanja ne nasleđuje pravo na međunarodnopravni subjektivitet..."

${ }^{3}$ Continuation by the Republic of Serbia of membership of the State Union of Serbia and Montenegro in the Council of Europe: Declaration by the Committee of Ministers of the Council of Europe CM(2006)104 (Deklaracija usvojena na 967. sastanku zamenika ministara) https://wcd. coe. int
}

${ }^{1}$ Rezolucija Res(2003)3, Poziv Srbiji i Crnoj Gori da postane član Saveta Evrope, 
procedura prijema koja je pre svega uključivala pozitivna mišljenja nakon istraživačkih poseta pojedinih komiteta PSSE za šta su jugoslovenske vlasti dale zeleno svetlo. Predsednik Predsedništva SFRJ Janez Drnovšek je prihvatio poziv da se obrati PSSE povodom Dana pobede 1990. godine. (Drnovšek se zaista obratio poslanicima PSSE 8. maja $1990 .{ }^{4}$ i istakao jugoslovensko opredeljenje za evropske integracije, posebno kroz članstvo u EEZ i SE. U vrlo živoj raspravi koja je usledila nakon govora, najviše je bilo reči o Kosovu i Metohiji i politici nesvrstavanja, kao i o ekonomskim i političkim reformama u Jugoslaviji.) U januarskim razgovorima s Bjorkom bilo je reči i o eventualnom slanju tima posmatrača PSSE na predstojeće jugoslovenske izbore, ali ta ideja je kasnije bila odbačena zbog izuzetno komplikovane procedure akreditacije i pored saglasnosti državnog vrha. ${ }^{5}$

U izveštaju o poseti navodi se da su jugoslovenski zvaničnici kako izvršne tako i zakonodavne vlasti u razgovorima često iskazivali bojazan da se javno mnjenje u Evropi i svetu pomalo distanciralo od Jugoslavije i ignorisalo vrlo aktuelne promene $u$ njoj, u svetlu dešavanja u Evropi posle pada Berlinskog zida. To, kako su naglašavali, posebno ugrožava dalju stabilnost zemlje jer je u prošlosti Jugoslavija bila i više nego podržavana $u$ svojoj politici zbog specifičnog položaja koji je zauzimala između Istoka i Zapada. ${ }^{6}$

Kada je reč o odnosima sa SE, svi su odreda isticali da je status specijalnog gosta koji zemlja uživa u PSSE samo međustanje i da Jugoslavija mora postati punopravan član te najstarije evropske političke organizacije. Posebno su ukazivali na to da je u Jugoslaviji, kako su govorili, već dugo na delu proces postepenog napredovanja ka demokratiji kroz samoupravljanje, koji je daje najbolje rezultate, nasuprot „demokratiji preko noći“ kako su nazivali zbacivanje komunističkih režima u ostalim zemljama Istočne i Centralne Evrope.

Tada je za Politički komitet, Pravni komitet i Komitet za odnose sa evropskim zemljama koje nisu članice SE pripremljen nacrt izveštaja o prijemu Jugoslavije u Savet Evrope. Izvestioci, među kojima je bio i budući predsednik Parlamentarne skupštine Migel Anhel Martines, zaključili su da Jugoslavija treba da bude uključena u širi proces evropskih integracija, posebno u Savet Evrope, čim u njenim republikama i autonomnim pokrajinama budu održani slobodni izbori, tim pre što se SFRJ obavezala da će ratifikovati Evropsku konvenciju za zaštitu ljudskih prava i osnovnih

${ }^{4}$ Arhiv PSSE, Official Report of Debates Vol. I, Forty-second Ordinary Session, 7-11 May 1990, pp. 48-52.

5 Arhiv PSSE, Visit by the President of the Parliamentary Assembly to Yugoslavia (1618 January 1990$)$.

${ }^{6}$ Isto. 
sloboda (uključujući tu i njene opcione odredbe) bez izražavanja bilo kakvih teritorijalnih rezervi. Jugoslavija je, međutim, sve više grabila u provaliju, tako da ovaj izveštaj nikada nije ni predočen na razmatranje Parlamentarne skupštine Saveta Evrope ${ }^{7}$. U pitanju je bila trka sa vremenom, da li će iznutra podriven komunistički politički sistem sa svim svojim posebnostima izdržati do trenutka prijema u Savet Evrope, ili će sama država nestati i urušiti se unutrašnjim sukobima, implozijom. U Jugoslaviji se već uveliko razbuktavaju centrifugalni procesi: odnosi između Albanaca i Srba na Kosovu i Metohiji neprestano se pogoršavaju, a ostale republike naglo počinju se protive onome što su tumačile i predstavljale kao dominaciju Srbije u federaciji.

Posle referenduma održanog u Sloveniji 23. decembra ${ }^{8}$ Savet Evrope je još pomnije pratio situaciju u Jugoslaviji, ali nije odstupao od ranije donetih zaključaka o potrebnim uslovima za punopravno članstvo zemlje. Konstatuje se da su tokom 1990. u svim republikama članicama održani parlamentarni izbori, sa različitim izbornim rezultatima, kao i da su očekivani izbori za Skupštinu SFRJ još jedini preostali formalni uslov za punopravno članstvo u SE. ${ }^{9}$ Jugoslavija je do tada uveliko otpočela usaglašavanje zakonodavstva sa kriterijumima Saveta Evrope, ratifikovala 12 konvencija i okvirnih sporazuma i izrazila punu spremnost za pristupanje Evropskoj konvenciji za zaštitu ljudskih prava i osnovnih sloboda. ${ }^{10} \mathrm{U}$ republikama je već uspostavljeno višestranačje, dok su u Skupštini SFRJ poslanici još uvek bili samo članovi SKJ. Savet Evrope je i zvaničnim putem bio obavešten o novonastalim strankama na prostoru Jugoslavije. Tako je obimna informacija o svakoj pojedinačnoj partiji bila upućena preko Generalnog konzulata Jugoslavije u Savet Evrope. ${ }^{11}$ U PSSE je tada zaključeno da se pred SFRJ mora postaviti još jedan uslov, a to je puna funkcionalnost države. ${ }^{12}$

Zbog izuzetno složene procedure donošenja odluka u SFRJ, gde je svaki republički parlament morao ponaosob da ratifikuje sve međunarodne dokumente, pa tako i konvencije SE, procedura ispunjenja obaveza je mogla

\footnotetext{
${ }^{7}$ Bruno Haller, An Assembly for Europe, The Council of Europe's Parliamentary Assembly 1949-1989, Strasbourg, 2006, r 198.

${ }^{8}$ Parlament SR Slovenije je u julu 1990. izglasao Deklaraciju o suverenosti Republike Slovenije. Saglasno Deklaraciji 23. decembra je održan referendum na koji je izašlo $93,2 \%$ od ukupnog broja upisanih birača i gde je $88,2 \%$ glasalo za osamostaljenje Slovenije.

${ }^{9}$ Arhiv PSSE, Restricted, AS/Pol (42) 20 rev, 7 January 1991.

${ }^{10}$ Arhiva predsednika PSSE, pismo Dušana Popovskog predsedniku PSSE 7. januara 1991.

${ }^{11}$ Arhiva predsednika PSSE, N 519/90 Lettre de Consulat Général de la RSFY, le 11 avril 1990.

${ }^{12}$ Arhiv PSSE, Restricted, AS/Pol (42) 28, 3 January 1991.
} 
da bude unekoliko usporena. Slovenački parlament je to i delimično iskoristio, uputivši zvaničan zahtev da njegovi poslanici u zvaničnom svojstvu ili neformalno učestvuju na zasedanjima PSSE, pozivajući se na činjenicu da je već ratifikovao brojne dokumente SE. ${ }^{13}$ Zahtev nije naišao na podršku zvaničnika PSSE, ali su poslanici Parlamenta Slovenije od aprila te, 1991. godine u neformalnom svojstvu boravili u Strazburu i pratili rad PSSE.

U narednim mesecima, koje su bili i poslednji mirni dani u SFRJ, povremeno je u PSSE pokretano pitanje o opstanku zemlje, kao i o eventualnoj promeni granica, ${ }^{14}$ ali i o poštovanju ljudskih prava, odnosno o stanju na Kosovu i Metohiji. ${ }^{15}$ Na Vidovdan 1991. godine, Parlamentarna skupština Saveta Evrope je jednoglasno usvojila deklaraciju u kojoj se osuđuje svaka upotreba nasilja u Jugoslaviji posle proglašenja nezavisnosti SR Slovenije i SR Hrvatske i poziva na obostrano prihvatljive mirne pregovore pod pokroviteljstvom Evrope i OEBS.

Predsednik PSSE Anders Bjork je 3. jula 1991. najoštrije osudio, kako je rekao, vojni udar u Jugoslaviji kojim su podriveni demokratski procesi demokratski izabrane vlade u Sloveniji i Hrvatskoj. Bjork je tom prilikom podsetio da Jugoslavija uživa status specijalnog gosta u PSSE, kao i da je zatražila punopravno članstvo $u$ toj organizaciji, o čemu je u toku odlučivanje. Naveo je da PSSE u potpunosti podržava mirovnu inicijativu EEZ-a i OEBS-a (KEBS) i traži od svih strana u sukobu - savezne vlasti, slovenačkog i hrvatskog rukovodstva - da se priklone mirovnim inicijativama i da prihvate eventualno slanje posmatrača $u$ želji da se na miran način pronađe dugotrajno rešenje sukoba.

$\mathrm{Na}$ jesenjem zasedanju PSSE je usvojila rezoluciju broj $969 \mathrm{O}$ krizi u Jugoslaviji u kojoj se osuđuje upotreba sile, traži povratak pregovorima, ali i traži i od UN da upute na teren mirovne trupe koje bi osigurale poštovanje primirja do konačnog rešenja budućnosti Jugoslavije. Takođe je zatraženo i ukidanje Jugoslaviji statusa specijalnog gosta u PSSE, čime bi se faktički dao negativan odgovor na zahtev u prijem u punopravno članstvo u Savetu Evrope. Taj predlog je $\mathrm{u}$ ime petnaest poslanika PSSE podneo ser Rasel Džonston, ${ }^{16}$ a ostali potpisnici bili su članovi liberalno-demokratske političke grupe (ALDE). ${ }^{17}$ Pošto su se nadležni komiteti PSSE pozitivno

13 Arhiva predsednika PSSE, pismo Matjaža Šinkovca predsedniku PSSE 7. januara 1991.

${ }^{14}$ Arhiv PSSE, Doc. 6431, presented by Sir Russel Johnston, 25 April 1991.

${ }^{15}$ Arhiv PSSE, Doc. 6466, 5 July 1991.

${ }^{16}$ Arhiv PSSE, Sir Russel Johnston letter on 20 September 1991 (Rasel Džonston tada još nije dobio lordovsku titulu).

${ }^{17}$ Potpisnici zahteva su bili: Rasel Džonston, Oli Ren, Soares Kosta, Elizabet Arnold, Ištvan Sent-Ivanji, Šarl Gerens, Mirja Rinenen, Sirka-Lisa Atila, Jan Verbek, Irena Grendelmajer, Dik Des, Karolj Tot, lord Maki, Masimo Pini i Kornelija fon Tajhman. 
izjasnili o suspenziji statusa specijalnog gosta Jugoslaviji u PSSE, identičnu odluku doneo je Biro Skupštine na sednici održanoj 25. novembra 1991, na kojoj je dat specijalni status Albaniji i najavljen isti takav status Sloveniji. ${ }^{18}$

Obaveštene o suspenziji, jugoslovenske vlasti su protestovale zbog, kako su navele, jednostranog prekidanja kvalitetnog dijaloga koji je u slučaju Jugoslavije trajalo još od sredine 50-ih godina. U pismu predsedniku PSSE Andersu Bjorku, predsednik Savezne skupštine Slobodan Gligorijević je podvukao da je stanje u Jugoslaviji teško jer se zemlja raspada iznutra i da je primetno da pojedini subjekti međunarodne zajednice jednostrano gledaju na raspad SFRJ, podržavajući isključivo one elemente koji su separatistički i ne žele opstanak države. Tražio je da Parlamentarna skupština, poštujući sopstveni Poslovnik, još jedanput preispita odluku o suspenziji. Bio je to poslednji i bezuspešan pokušaj SFRJ, odnosno Savezne skupštine, da nešto uradi na spasavanju odnosa sa Savetom Evrope. ${ }^{19}$

Tako je prekinuta najdugovečnija saradnja Saveta Evrope sa nekom komunističkom zemljom, saradnja čiji su koreni sezali do polovine pedesetih godina 20. veka.

Drugi zvaničan zahtev za prijem upućen je neposredno posle petooktobarskih promena, ${ }^{20}$ ali ni on nije odmah doneo očekivan rezultat. Tek u trećoj kalendarskoj godini posle tih promena, uz mnogobrojne izazove, stroge uslove, pa čak i uvođenje mehanizama kao što je dvostruki monitoring koji nikada ranije nisu primenjivani, Jugoslavija - tada već kao Državna zajednica Srbija i Crna Gora - postala je 45. članica Saveta Evrope. To se dogodilo u vreme kada je u njoj posle atentata na dr Zorana Đinđića, prvog demokratski izabranog predsednika Vlade Republike Srbije 9. marta 2003, bilo uvedeno vanredno stanje. Istini za volju, valja reći da je na promene koje su doneli izbori od 24. septembra 2000. Savet Evrope reagovao i pre nego što je iz Beograda stigao obnovljen zahtev za članstvo. Komitet ministara Saveta Evrope je 25. oktobra 2000. doneo odluku u kojoj je izdao uputstvo Sekretarijatu da nastavi planiranje saradnje sa Saveznom Republikom Jugoslavijom i da ispita mogućnost osnivanja kancelarije Saveta Evrope u Beogradu, čim novi nadležni organi zauzmu svoje pozicije, $\mathrm{u}$ tesnoj saradnji sa relevantnim međunarodnim organizacijama (pre svega Evropskom unijom, OEBS-om i Ujedinjenim nacijama) uzimajući u obzir projekte koji su razrađeni u okviru Pakta stabilnosti za Jugoistočnu Evropu.

\footnotetext{
${ }^{18}$ Arhiv PSSE, Communique de presse, Ref:483 (91), 25 Novembre 1991.

19 Arhiva predsednika PSSE, pismo Slobodana Gligorijevića Andersu Bjorku, predsedniku PSSE, 9. decembar 1991.

${ }^{20}$ Arhiva predsednika SRJ, Informacija o poseti predsednika SRJ Savetu Evrope u Strazburu, 11. novembar 2000.
} 
Potom je Stalni komitet, postupajući u ime PSSE, 9. novembra 2000. doneo preporuku 1481 (2000) kojom sugeriše Komitetu ministara da pozove zemlje članice da pruže Jugoslaviji masivnu humanitarnu pomoć, ali i pomoć u jačanju demokratske odgovornosti policije i nezavisnosti pravosuđa, kao i da, što je pre moguće, otvori kancelariju u Beogradu i da redefiniše svoje prisustvo u Crnoj Gori i na Kosovu.

Istog dana Stalni komitet je, opet u ime PSSE, doneo Rezoluciju $1230(2000)^{21}$ u kojoj se navodi da Parlamentarna skupština čestita Vojislavu Koštunici na izboru za predsednika SRJ i izražava mu punu podršku u naporima da obezbedi mirnu tranziciju svoje zemlje $u$ demokratiju. Sem toga, PSSE upućuje čestitke narodu Jugoslavije na izboru i borbi za demokratiju i slobodu, odajući priznanje demokratskim snagama koje su pomogle da se obezbedi pobeda predsednika Koštunice na izborima.

Ta rezolucija ima 16 tačaka od kojih se u većini, osim uvodnih čestitki novoizabranom predsedniku i narodu SRJ i pohvale odluci Brisela da ukine sve sankcije koje su protiv SRJ bile na snazi od 1998. godine, na ovaj ili onaj način govori o uslovima koje SRJ treba da ispuni. Tako se $u$ tački pet pozdravlja prijem SRJ u punopravno članstvo Pakta stabilnosti Jugoistočne Evrope 26. oktobra 2000, odnosno članstvo u Ujedinjenim nacijama, 1. novembra 2000 , da bi se odmah potom "uputilo ohrabrenje“ SR Jugoslaviji da, što je pre moguće, ispuni uslove koji će joj omogućiti da nađe svoje mesto i u drugim međunarodnim organizacijama, pre svega Savetu Evrope i OEBS. Kada se danas još jednom iščitaju tekstovi dokumenata Saveta Evrope koji su se 2000. odnosili na SRJ, pre svega tekst rezolucije 1230, može se videti da je već tada bilo izvesnih naznaka da neće sve teći glatko ni sa prijemom u Savet Evrope, ni sa ukupnim uključivanjem u evropske integrativne tokove. Tako se u tački 9 kaže da „... PSSE podseća da održavanje slobodnih i demokratskih izbora, sprovođenje demokratskih reformi u celoj zemlji, funkcionisanje demokratskog političkog sistema, poštovanje vladavine prava i zaštite ljudskih prava, uključujući tu prava lica koja pripadaju nacionalnim manjinama, predstavljaju ključne uslove koje Savezna Republika Jugoslavija treba da ispuni da bi, kada za to dođe vreme, postala punopravna članica Saveta Evrope."

I dalje, u tački 10: „Skupština je svesna sadašnje krhkosti demokratskih institucija u Saveznoj Republici Jugoslaviji i smatra da u ovoj fazi ti uslovi još nisu ispunjeni. Ipak, ona je čvrsto rešena da radi u korist demokratskih promena u zemlji, kako bi ona što je pre mogućno mogla da pristupi Savetu Evrope".

${ }^{21}$ www.assembly.coe. int Tekst usvojen na zasedanju Stalnog komiteta 9. novembra 2000. 
Tačka 13: „Kada je reč o Kosovu, Skupština primećuje da je rezultate lokalnih izbora koji su održani 28. oktobra 2000, koje je prihvatila privremena administrativna misija Ujedinjenih nacija na Kosovu (UNMIK) na osnovu pozitivne ocene izborne posmatračke misije Saveta Evrope. S druge strane, Skupština podseća da Rezolucija Saveta bezbednosti Ujedinjenih nacija 1244 (1999) o situaciji na Kosovu mora biti u potpunosti sprovedena i da srpskoj manjini treba da bude pružena puna zaštita“.

Dalje se taksativno navode uslovi:

„Skupština poziva vlasti Savezne Republike Jugoslavije da:

i. uspostavi demokratski politički režim zasnovan na vladavini prava i zaštiti ljudskih prava, uključujući tu prava pripadnika nacionalnih manjina i da, u tom smislu, osnaži demokratsku odgovornost policije i pouzdanu nezavisnost pravosuđa;

ii. preduzme sve neophodne korake kako bi obezbedila da izbori za Narodnu skupštinu Republike Srbije koji će se održati 23. decembra 2000. budu slobodni i pravični;

iii. pozove međunarodnu zajednicu da posmatra te izbore;

iv. poštuje slobodu govora i izmeni postojeće zakonske propise $u$ toj oblasti, pre svega Zakon o javnom informisanju koji je Narodna skupština Republike Srbije donela 20. oktobra 1998;

v. informiše stanovništvo Savezne Republike Jugoslavije o zločinima koje je počini Miloševićev režim i da sarađuje sa Međunarodnim krivičnim tribunalom za bivšu Jugoslaviju, kako bi se postiglo rešenje koje će biti u interesu pravde i same zemlje;

vi. nastavi dijalog sa vlastima u Crnoj Gori, radi razjašnjavanja najdelotvornijeg okvira za odnose između Srbije i Crne Gore;

vii. sarađuje sa UNMIK-om na Kosovu, angažujući se $u$ konstruktivnom dijalogu $\mathrm{u}$ duhu pomirenja sa izabranim albanskim vođima i da oslobodi političke zatvorenike iz redova kosovskih Albanaca koji se još uvek nalaze u zatvorima u Srbiji;

viii. istraži sudbinu Srba i kosovskih Albanaca koji su nestali;

ix. započne proces pomirenja sa susednim zemljama i ponovo uspostavi odnose zasnovane na poverenju i saradnji, posebno tako što će priznati Bosnu i Hercegovinu kao nezavisnu, suverenu državu, $u$ potpunosti se povinujući Dejtonskom mirovnom sporazumu i priznajući postojeću granicu sa „Bivšom Jugoslovenskom Republikom Makedonijom“;

$\mathrm{x}$. preduzme sve neophodne mere da bi razjasnila sudbinu $\mathrm{g}$. Stambolića, bivšeg predsednika Srbije i nekadašnjeg mentora Slobodana Miloševića, i drugih ljudi čiji nestanak ili ubistva još nisu razjašnjeni;

xi. reši pitanja $u$ vezi sa sukcesijom Socijalističke Federativne Republike Jugoslavije (SFRJ) i da, što je pre moguće, ispuni neophodne 
uslove kako bi Savezna Republika Jugoslavija mogla da zauzme svoje mesto u međunarodnim organizacijama kao jedna od zemalja naslednica SFRJ“.

Pored toga, u tački 16, izdvojeno od prethodnih stavki, Skupština „poziva nadležne vlasti da preduzmu odgovarajuće korake kako bi se postarali da Srbi koji su napustili Kosovo mogli da se vrate u svoje domove i da nastave normalan život, uz sva jemstva koja im pruža vladavina prava“.

Odgovarajući na zahtev za prijem koji je, takođe 9. novembra 2000, podnela novoizabrana savezna vlada, Komitet ministara je usvojio rezoluciju od 22. novembra $2000,{ }^{22}$ istakavši da "postoji konsenzus među zemljama-članicama u korist prijemu SR Jugoslavije, kao jedne od ravnopravnih država naslednica bivše Socijalističke Federativne Republike Jugoslavije u Organizaciju (Savet Evrope) čim budu ispunjeni uslovi koje nalaže statut, a koji se odnose na primenu načela pluralističke demokratije, poštovanje ljudskih prava i vladavine prava. To podrazumeva da zakonodavni i pravosudni sistem $\mathrm{u}$ zemlji treba da budu usklađeni $\mathrm{s}$ načelima vladavine prava."

Navedeno je, takođe, da Komitet ministara pozdravlja nameru SRJ da postane visoka strana ugovornica Okvirne konvencije o zaštiti nacionalnih manjina. Pored toga, Komitet je potvrdio spremnost da produbi dijalog sa vlastima SRJ i da uspostavi saradnju i organizuje programe pomoći za tranziciju SRJ u demokratiju, kao i za zakonodavnu reformu i reformu državne uprave u njoj.

Skoro dve godine kasnije, 24. septembra 2002, PSSE je razmatrala zahtev SRJ za prijem iz novembra 2000. i donela Mišljenje br. 239 (2002), ubedljivom većinom prisutnih preporučivši Komitetu ministara da donese odluku o prijemu SR Jugoslavije u punopravno članstvo Saveta Evrope. Za prijem Jugoslavije glasala su 122 poslanika, njih 6 je bilo protiv, a 4 uzdržana. Kao uslov za prijem, uz postojeće, postavljeno je da parlamenti Srbije i Crne Gore do tada usvoje ustavnu povelju buduće državne zajednice (nekoliko meseci pre toga, 14. marta 2002. u Beogradu su potpisane Polazne osnove za preuređenje odnosa Srbije i Crne Gore). Na dokument o prijemu Jugoslavije koji su poslanicima u Strazburu podneli specijalni izvestilac Političkog komiteta Klod Frej iz Švajcarske i njegov kolega iz Nemačke Helmut Lipelt, kao izvestilac Komiteta za politička pitanja i ljudska prava, usvojeni su i amandmani koji se odnose na obavezu Jugoslavije da kažnjava lica koja su počinila ratne zločine, da poštovanje prava manjina bude regulisano na saveznom nivou, kao i amandman kojim se garantuje da će državna zajednica Srbije i Crne Gore poštovati sve one obaveze koje je preuzela SRJ.

${ }^{22}$ Resolution Res(2000)15, koju je Komitet ministara usvojio na 730. sastanku zamenika ministara 22. novembra 2000. 
Savezna skupština je 4. februara 2003. proglasila Ustavnu povelju Državne zajednice Srbija i Crna Gora. Usledila je razmena pisama između predsedavajućeg Komiteta ministara i vlasti Srbije i Crne Gore, 19. i 20. marta, da bi 26. marta Komitet ministara pozvao SCG u punopravno članstvo; prijem je konačno realizovan 3. aprila 2003.

Osnovni ciljevi Saveta Evrope su zaštita ljudskih prava, unapređenje demokratije i vladavine prava, i ova organizacija pruža pomoć državama članicama pre svega u domenu pravnog i institucionalnog uređenja države, sprovođenja reformi u pravosuđu i drugim oblastima u kojima je SE, na osnovu svog mandata, aktivan.

Od preko 200 konvencija i protokola Saveta Evrope, Republika Srbija je do sada ratifikovala 77 konvencija Saveta Evrope, a potpisala 8, koje čekaju potvrđivanje u Narodnoj skupštini RS. Najznačajniji među tim instrumentima jesu Konvencija za zaštitu ljudskih prava i osnovnih sloboda (koja predstavlja osnov evropskog sistema zaštite ljudskih prava), Okvirna konvencija za zaštitu nacionalnih manjina, Evropska povelja o regionalnim i manjinskim jezicima.23 Republika Srbija je članica 11 parcijalnih sporazuma Saveta Evrope, koji predstavljaju fakultativni oblik okupljanja država koje poseban interes iskazuju za određenu oblast aktivnosti SE: Grupa zemalja za borbu protiv korupcije - GREKO, Evropska farmakopeja, Banka za razvoj SE, Evropski potporni fond za koprodukciju i distribuciju kreativnih kinematografskih i audio-vizuelnih radova - EURIMAGES, Evropska komisija za demokratiju putem prava - Venecijanska komisija, Prošireni parcijalni sporazum o sportu, Centar Sever-jug, Evropski i mediteranski sporazum o katastrofama (EUR-OPA), Grupa za borbu protiv zloupotrebe i nezakonitog prometa narkotika Saveta Evrope (Pompidu grupa), Omladinska karta, Putevi kulture.

Period posle 2003, od kada je tada već država pod imenom Srbija i Crna Gora postala punopravna članica Saveta Evrope, obeležilo je učešće delegacije u PSSE prvo Skupštine SCG (do 2006), a zatim NSRS u formatu sedam stalnih članova delegacije i sedam zamenika. Tokom prve decenije punopravnog članstva promenjeno je pet stalnih delegacija (dve Skupštine SCG i tri NSRS), uz povremene personalne izmene u njima. Primetno je da je učinak sastava određene delegacije u PSSE često zavisio od aktivnosti šefa, ali neretko postoji i lična inicijativa članova, čime je ugled delegacije, pa i Republike Srbije, rastao među ostalim poslanicima PSSE. Pored tema koje su bile direktno vezane za interese Republike Srbije, pojedini poslanici 
su se bavili i temama od opšteg interesa, poput glasačkog prava, prava i diskriminacije Roma u Evropi i sl.

Kada je reč o temama u PSSE od interesa za Republiku Srbiju, u periodu 2004-2012. usvojene su brojne rezolucije koje se tiču Srbije. Od toga se osam rezolucija direktno odnosilo na Kosovo i Metohiju. ${ }^{24}$ Posebno su se isticale dve rezolucije o Kosovu i Metohiji koje je predlagao pokojni lord Rasel Džonston, neskriveni pobornik nezavisnosti Kosova, od 2006. do 2008. godine. ${ }^{25}$ Tada su, i pored ogromnog pritiska, kako nekih poslanika, tako i dela javnosti, delegacije (prvo Skupštine SCG, a zatim i NSRS) izmenile suštinu teksta i postigle statusnu neutralnost pomenutih rezolucija.

Najviše pažnje, kako međunarodne, tako i one u Srbiji i regionu, privukao je verovatno najveći uspeh srpske delegacije u PSSE - postignut usvajanjem izveštaja Dika Martija o trgovini ljudskim organima na Kosovu i Metohiji. $^{26}$ U izveštaju bivšeg državnog tužioca kantona Tičino u Švajcarskoj istaknuta je moralna obaveza da se reše užasni zločini, kao i da se rasvetli sudbina nestalih. Imenovani su Drenička grupa OVK i sadašnji premijer privremenih institucija u Prištini Hašim Tači i njegovi saradnici, kao najodgovorniji za nestanke zarobljenih i trgovinu organima. Takođe je osvetljen i značaj klinike „Medikus" u nelegalnim transplantacijama ljudskih organa. Kvalitetna saradnja izvestioca Dika Martija sa članovima srpske delegacije tokom izrade njegovog izveštaja, ali i sa državnim organima nekoliko država članica Saveta Evrope, bila je od presudne važnosti, posebno ako se imaju na umu svi problemi koje je istraga imala sa stalnim zastrašivanjima svedoka, dok je sam Dik Marti bio nazivan nosiocem „prljave kampanje protiv Kosova“. ${ }^{27}$

Članovi srpske delegacije u PSSE su tokom protekle decenije inicirali raspravu o pojedinim temama od važnosti za Srbiju (stanarska prava izbeglih lica, poštovanje ljudskih i verskih prava, preispitivanje priznanja Kosova i Metohije, ali i pitanje očuvanja starih zanata, propisanog uzrasta za glasanje i sl.). Pored toga, intenzivno su radili da se

${ }^{24}$ Savet Evrope nikada nije priznao jednostrano proglašenu nezavisnost Kosova, uprkos jakom pritisku. Danas ipak postoje najave da će Priština imati neku vrstu posmatračkog statusa u PSSE.

25 Rezolucije PSSE 1453 (2005) i 1533 (2007), detaljnije: http://assembly.coe. int/ASP/Doc/XrefATListing_E. asp, sajtu pristupljeno 24. marta 2013. godine.

${ }^{26}$ Rezolucija 1782, od 25. januara 2011 (Investigation of allegations of inhuman treatment of people and illicit trafficking in human organs in Kosovo), detaljnije videti na: http://assembly.coe. int/ASP/Doc/XrefATListing_E. asp (24. mart 2013).

27 Peticiju protiv izveštaja Dika Martija potpisalo je više od 230.000 Albanaca iz Albanije, Makedonije i sa Kosova i Metohije. Takođe, albanski političari su listom napadali izvestioca, optužujući ga za rasizam. 
privede kraju proces monitoringa PSSE nad Srbijom i da se to pitanje konačno zatvori. ${ }^{28}$

Posebno važno priznanje Republika Srbija je imala kada je i pored monitoring procedure PSSE koja se još uvek sprovodi nad njom, predsedavala Komitetom ministara Saveta Evrope u periodu maj-novembar 2007. koje je ocenjeno kao potvrda posvećenosti Republike Srbije evropskim vrednostima, poštovanju ljudskih prava i vladavini prava. ${ }^{29}$

\section{Prilog}

Dokumenti PSSE koji se odnose na Srbiju ili su ih predložili srpski poslanici u periodu 2003-2013:

Preporuka o interno raseljenim licima u Evropi, (br. 1631), Terezija Stoisits (Austrija), 2003.

Rezolucija o funkcionisanju demokratskih institucija u Srbiji i Crnoj Gori, Miloš Budin i Jonas Čekuolis (br. 1397), 2004.

Rezolucija o zaštiti ljudskih prava na Kosovu, Toni Lojd (1417) 2005.

Rezolucija o trenutnom stanju na Kosovu, Marijana Tric (br. 1453), 2005.

Rezolucija o dobroj praksi prilikom održavanja referenduma u Evropi, Mika Elo (br. 1704), 2005.

Rezolucija o situaciji na Balkanu, Maćaš Erši (br. 1517), 2006.

Rezolucija o trenutnom stanju na Kosovu, lord Rasel Džonston (1533), 2007.

Rezolucija o fokusu Evropske banke za rekonstrukciju i razvoj (EBRD) na Istočnu i Jugoistočnu Evropu, Karl Gasoliba (br. 1561), 2007.

Rezolucija o tajnim zatvorima i prebacivanjima pritvorenika u zemljama članicama Saveta Evrope, Dik Marti (br. 1562), 2007.

Rezolucija o saradnji sa Međunarodnim tribunalom za ratne zločine počinjene na prostoru bivše Jugoslavije u Hagu, Toni Lojd (br. 1564), 2007.

Rezolucija o situaciji u kojoj žive deca u postkonfliktnim zonama na Balkanu, Karina Olson (br. 1587), 2007.

Rezolucija o tajnom glasanju, Miloš Aligrudić, (br. 1590), 2007.

Rezolucija o izbeglim i raseljenim licima u Jugoistočnoj Evropi, Nikos Dendias (br. 1801), 2007.

Rezolucija o dešavanju na Kosovu u svetlu budućeg statusa, lord Rasel Džonston (br. 1595), 2008.

\footnotetext{
28 Rezolucija 1858, od 25. januara 2012, više videti na: http://assembly.coe. int/ASP/XRef/X2H-DW-XSL. asp? fileid=18065\&lang=EN (24. mart 2013).

${ }_{29} \mathrm{http} / /$ hub. coe. int/web/coe-portal/event-files/chairmanship-committee-ofministers/serbia-may-november-

2007 ?dynLink=true \&layoutId=318\&dlgroupId=10226\&fromArticleId
} 
Rezolucija o položaju manjina u Vojvodini i rumunske u Srbiji, Jirgen Herman (br. 1632), 2008.

Rezolucija o starim zanatima i kulturnom nasleđu konzervacije, baronesa Huper (br. 1851), 2008.

Rezolucija o funkcionisanju demokratskih institucija u Srbiji, Šarl Gorens i Andreas Gros (br. 1867), 2009.

Rezolucija o situaciji na Kosovu* i uloga Saveta Evrope, Bjorn fon Sidov (br. 1739), 2010.

Mišljenje o položaju Roma u Evropi i aktivnostima Saveta Evrope, Elvira Kovač (br. 12236), 2010

Rezolucija o nehumanom postupanju s ljudima i trgovini ljudskim organima na Kosovu Dik Marti (br. 1782), 25. januar 2011.

Rezolucija o zaštiti svedoka kao kamen temeljac za pravdu i pomirenje na Balkanu, Žan Šarl Gardeto (br. 1784), 2011.

Preporuka „Ka okvirnoj evropskoj konvenciji o pravima omladine“, Elvira Kovač (br. 1978), 2011.

Rezolucija o širenju demokratije spuštanjem starosne granice biračkog prava na 16 godina, Miloš Aligrudić, (br. 1826), 2011.

Rezolucija o političkoj situaciji na Balkanu, Bjorn fon Sidov (br. 1839), 2011.

Rezolucija o psihološkom nasilju, Elvira Kovač (br. 1852), 2011.

Rezolucija o funkcionisanju demokratskih institucija u Srbiji, Davit Harutjunjan i Indrek Saar, (br. 1858), 2012.

Mišljenje o Romima migrantima u Evropi, Miloš Aligrudić, (br. 3722), 2012.

Rezolucija o situaciji na Kosovu* i uloga Saveta Evrope, Bjorn fon Sidov (br. 1912), 2013.

\section{Zahtev za Rezoluciju}

Nečovečno postupanje s ljudima i trgovina ljudskim organima na Kosovu, Konstantin Kosačev (br. 11574), 2008.

i lobiranje u junu 2008. da Dik Marti prihvati da napiše izveštaj (Rezolucija br. 1782, 25. januar 2011)

* Ova oznaka ne prejudicira stavove o statusu, i u skladu je s Rezolucijom 1244/99 Saveta bezbednosti UN i Mišljenjem Međunarodnog suda pravde (MSP) o Deklaraciji o proglašenju nezavisnosti Kosova (stalna napomena u svim dokumentima SE uz toponim Kosovo). 


\section{Zahtev za Preporuku}

Evropska konvencija o zaštiti starih i tradicionalnih zanata, Miloš Aligrudić (br. 11268), 2007.

\section{Pisane deklaracije}

Slučaj kršenja ljudskih i verskih prava u Makedoniji - Vladika Jovan Vraniškovski, Ljubiša Jovašević (br. 371), 2005.

Položaj Srba proteranih iz RSK, Tomislav Nikolić (br. 478), 2006.

\section{Ratomir Milikić}

\section{3-2013: 10TH ANNIVERSARY OF SERBIA'S ACCESSION TO THE COUNCIL OF EUROPE}

\section{Summary}

The author highlights several problems that the Republic of Serbia (FRY, Serbia-Montenegro) has encountered on its way to permanent membership of the Council of Europe. It has had to cope with numerous barriers, in many aspects unique. The Federal Parliament adopted the Constitutional Charter of the State Union of Serbia and Montenegro on February 4th 2003, by which act the Federal Republic of Yugoslavia had ceased to exist. The Committee of Ministers invited the State Union of Serbia and Montenegro to become a full fledged member of the Council of Europe. The accession finally took place on April 3rd, but conditioned with a specific, unprecedented dual monitoring procedure. During the decade that followed, first Serbia-Montenegro, and from then on Republic of Serbia as the successor state, has often been forced to defend its interests concerning territorial integrity and sovereignty, while participating in the work of the $\mathrm{CoE}$ and its bodies. The most common issues involved Kosovo and Metohia, national minorities and religious communities rights, as well as the cooperation with the ICTY. The most important document for Serbia adopted by the PACE was a resolution calling for international and local investigations into illicit organ trafficking in Kosovo, based on a report written following a two-year investigation by Swiss rapporteur Dick Marty. Serbia chaired the Committee of Ministers for a six-month term from May to November 2007. After all the hardships it had to endure during the first ten years of its $\mathrm{CoE}$ membership, the Chairmanship came as a special honour and a long awaited recognition of the commitment of the Republic of Serbia to fundamental European values, democracy, respect for human rights and the rule of law. 